\title{
Типоморфные особенности самородного золота и электрума из северо-западного фланга Янисйокского благороднометалльного рудопроявления (Питкярантский район, Карелия)
}

\author{
Лавров О.Б. \\ Институт геологии КарНЦ РАН, Петрозаводск, petrlavrov@list.ru
}

\begin{abstract}
Аннотация. В работе рассмотрены типомофные особенности и состав самородного золота и электрума из северо-западного фланга Янисйокского благороднометалльного рудопроявления. Минералы изучались с использованием электронного сканирующего микроскопа VEGA II LSH (Tescan) с энергодисперсионным микроанализатором INCA Energy-350. Формы выделения носителей золота и серебра оказались весьма разнообразными: пластинчатыми, комковидными, пленочными и жилковидными. В зонах с повышенным содержанием арсенопирита установлены две генерации самородного золота и электрума. Установлен ютенбогаардтит - новый для данного рудопроявления минерал, содержащий $\mathrm{Au}$ и Ag.
\end{abstract}

Ключевые слова: Янисйокское благороднометалльное рудопроявление, арсенопирит, самородное золото, электрум, ютенбогаардтит, типоморфные особенности.

\section{Typomorphic characteristics of the native gold and electrum from the northwestern flanc of Janisjoki noble-metal ore occurrence (Pitkaranta region, Karelia)}

\author{
Lavrov O.B. \\ Institute of Geology, KarRC RAS, Petrozavodsk, petrlavrov@list.ru
}

\begin{abstract}
The typomorphic characteristics and composition of native gold and electrum from the northwestern flank of the Yanisjoki noble-metal ore occurrence are discussed. The minerals were studied using a VEGA II LSH (Tescan) scanning electron microscope with an INCA Energy-350 energy-dispersive microanalyzer. Gold and silverbearing aggregates displayed a variety of shapes: lamellar, clumpy, film-like and vein-like. Zones with elevated arsenopyrite concentrations were found to contain two generations of native gold and electrum. Jutenbogaardtite, an $\mathrm{Au}$ - and Ag-bearing mineral new to this ore occurrence, was revealed.
\end{abstract}

Keywords: Janisjoki noble-metal ore occurrence, arsenopyrite, native gold, electrum, uytenbogaardtite, typomorphic characteristics.

Исследователям, интересующимся вопросами металлогении Северного Приладожья, хорошо известно благороднометалльное проявление Янисйоки (Янис). Оно было выявлено в ходе геологопоисковых работ, выполняемых сотрудниками ГГУП СФ «Минерал» на территории Питкярантского района Республики Карелия в 2000 г. В 2001 в геолого-поисковых работах на площади рудопроявления и за ее пределами принимал участие и автор данной публикации. Рудопроявление, в основном, приурочено к трещинной интрузии тоналитов (преобладают), плагиогранитов и диоритов, слагающих г. Лоухиваара и ряд возвышенностей под общим названием Питкямяет.

Интрузия прорывает терригенные толщи калевийского надгоризонта палеопротерозоя, метаморфизованные в условиях амфиболитовой фации. Они представлены ритмичнослоистыми метапесчаниками, метаалевролитами субширотного простирания (на С3 фланге рудопроявления) а также андалузит-кордиеритсодержащими сланцами.

C3 фланг рудопроявления характеризуется наличием большого количества кулисообразных даек и апофиз тоналитовой интрузии, проявлением метасоматических изменений и сульфидной минерализации. Сам же дайковый рой прослеживается на 3 км к С3 от основной Янисйокской интрузии. На этом фланге дайки основного состава превращены в амфиболиты, кроме них встречаются тоналиты, тоналит-порфиры и диориторые порфириты. По периферии дайкового роя наблюдались единичные тела кварцевых порфиров. Ряд даек подверглись сдвиговым деформациям, рассланцеванию и пропилитизации. Метасоматиты отличаются аномальными содержаниями $\mathrm{As}, \mathrm{Pb}, \mathrm{Zn}, \mathrm{Bi}$, 
$\mathrm{Sb}, \mathrm{Cu}, \mathrm{Ag}, \mathrm{Mo}, \mathrm{W}$. C метасоматическими образованиями, контролируемыми левосдвиговыми разрывными нарушениями С-C3 простираний, сопряжены поперечные трещины скола. Они выполнены субширотными жилами и прожилками бесцветного кварца с крупнозернистым арсенопиритом и минералами $\mathrm{Au}, \mathrm{Ag}$.

Благороднометалльная минерализация локализуется также вдоль контактов даек С3 простирания с метатерригенными породами в маломощных зонах интенсивного окварцевания. Наиболее оруденелые участки содержат до 30-40 \% арсенопирита (у бывшего финского хутора Ууситало). Содержание золота в штуфных пробах, взятых из обогащенных арсенопиритом участков, достигает 3 г/т.

Биотитизация и окварцевание, реже - пропилитизация - характерные изменения, накладывающиеся на метатерригенные породы. Самая крупная по наблюдениям автора оруденелая зона по метаосадкам имеет мощность около 3 метров. В этих породах арсенопирит распространен в виде неравномерной вкрапленности призматических зерен размером до 2.0 мм, с ним ассоциируют пирротин, халькопирит, пирит, реже галенит и сфалерит.

Арсенопирит, встречающийся в кварцевых прожилках, представлен отдельными зернами призматического и ромбического сечения размером до 3.0-3.5 мм, в агрегатах его размер - от 0.1-0.24 мм до 8.0 мм. Как правило, зерна арсенопирита трещиноваты, частично замещены скородитом. Другие сульфиды, встречающиеся в кварцевых жилах: пирротин, халькопирит, молибденит и поздний марказит. Пирит образует кубического габитуса зерна размером до 2.5 мм, замещенные гидроокислами Fе.

При более детальном исследовании минералов продуктивной арсенопирит-кварцевой ассоциации с помощью электронного сканирующего микроскопа VEGA II LSH (Tescan) с энергодисперсионным микроанализатором INCA Energy-350 были установлены составы самородного золота и электрума, а также выявлен новый для данного объекта минерал - ютенбогаардтит (табл. 1).

Таблица 1. Химические составы самородного золота, электрума и ютенбогаардтита из северо-западного фланга Янисйокского благороднометального рудопроявления.

Table 1. Chemical compositions of native gold, electrum, and uytenbogaardtite from the northwestern flank of the Janisjoki noble-metal ore occurrence.

\begin{tabular}{|c|c|c|c|c|c|c|c|c|c|c|}
\hline Элементы & 1 & 2 & 3 & 4 & 5 & 6 & 7 & 8 & 9 & 10 \\
\hline $\mathrm{Au}$ & 73.81 & 76.87 & 79.90 & 85.70 & 52.35 & 56.74 & 60.79 & 64.41 & 34.91 & 31.61 \\
\hline $\mathrm{Ag}$ & 26.19 & 23.13 & 20.10 & 14.29 & 47.65 & 43.26 & 39.21 & 35.59 & 52.61 & 55.06 \\
\hline $\mathrm{S}$ & & & & & & & & & 12.48 & 13.33 \\
\hline
\end{tabular}

Примечание: 1-4 - самородное золото; 5-8 - электрум; 9-10 - ютенбогаардтит.

Самородное золото и электрум в кварцевых прожилках образуют субмикроскопические включения в арсенопирите размером около 1 мкм. Кроме того, наблюдались выделения пленочного золота в срастании с магнетитом в одном случае и с шеелитом (размер 10 мкм) в другом среди арсенопирита (рис. 1 а). Трещины в последнем иногда выполняет пленочное золото. Пробность его достигает $820 \%$.

Электрум формирует удлиненные зерна размером 25 мкм, напоминающие микропрожилки, локализующиеся в скородите между зернами измененного арсенопирита и в относительно «свежем» арсенопирите. В последнем случае электрум с двух сторон обрастает оторочкой ютенбогаардтита (рис. 1 в).

Отдельные «нити» этого минерала проникают по трещинам в арсенопирит. Содержание Аu в электруме, который встречался в относительно крупных выделениях, варьирует незначительно: от $54.20 \%$ в краевой части зерна до 55.23 \% в центре.

Среди других рудных минералов, встречающихся в кварцевых прожилках, следует упомянуть микропластинчатый молибденит, галенит, серебросодержащий $(\mathrm{Ag}-12.5$ \%) галенит и теллурид висмута.

В зонах с богатой арсенопиритовой минерализацией самородное золото и электрум встречаются в виде зерен комковидной формы размером от 5 до 15-17 мкм. Пробность золота - 829 \%о. Оба минерала также образуют тончайшие пленки в трещинах индивидов арсенопирита. Причем, и золото, и электрум пленочной формы характеризуются большим содержанием Ag по срав- 

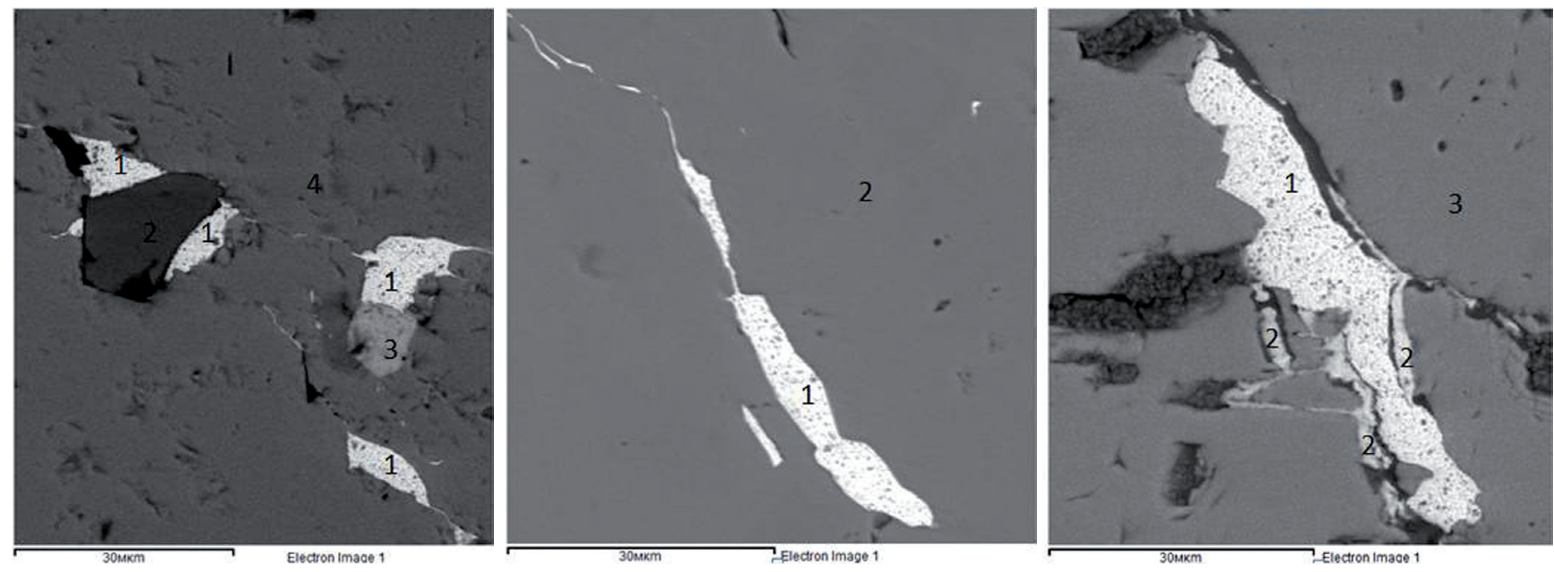

Рис. 1. Самородное золото, электрум и ютенбогаардтит среди арсенопиритовой минерализации северозападного фланга Янисйокского благороднометального рудопроявления: а - срастание самородного золота (1) с магнетитом (2) и шеелитом (3) в арсенопирите (4); в - электрум (1) и ютенбогаардтит (2) в арсенопирите (3); с - электрум (1) в арсенопирите (2).

Fig.1. Native gold, electrum and uytenbogaardtite among the arsenopyrite mineralization of the northwestern flank of Janisjoki noble-metal ore occurence: a - coalescence of native gold (1) with magnetite (2) and scheelite (3) in arsenopyrite (4); b - electrum (1) and uytenbogaardtite (2) in arsenopyrite (3); c-electrum (1) in arsenopyrite (2).

нению с теми же минералами комковидной формы. Соответственно, золото содержит 21.8 \% Ag, электрум - 44.4 \% Ag. Очевидно, здесь наблюдаются разные генерации благородных минералов. Галенит и минералы системы Ag-Pb-Bi-S представлены в виде мельчайших включений в арсенопирите из богатых руд. Иногда галенит содержит до $10.4 \% \mathrm{Ag}$, а свинцово-висмутовые сульфосоли представляют собой высокосеребристые фазы (до 20 \% Ag).

В метатерригенных породах некоторые зерна арсенопирита обладают интересной особенностью - имеют неоднородное строение: внешняя кайма зерен более мышьяковистая, а внутренние участки - более сернистые (обратная зональность). Самородное золото комковидной формы и размером до 8 мкм встречается в зернах арсенопирита и в единичном случае - среди альбита. Его пробность достигает 762 \%. А вот самородное золото пластинчатой формы - более высокопробно - от 827 до 857 \%.

Электрум, как правило, распространен в виде удлиненных зерен размером $40 \times 13$ мкм или представлен жилковидной формой длиной до 60 мкм в зернах и трещинах арсенопирита (рис. 1 с). Его химический состав характеризуется однородностью. Между зернами кварца и арсенопирита, пирротина и арсенопирита локализуется цумоит (Bi $\square \mathrm{Te} \square)$, а в галените - самородный висмут.

Из особенностей распределения, форм нахождения самородного золота и электрума в кварцевых прожилках, зонах интенсивной сульфидизации и метасоматически измененных метатерригенных породах северо-западного фланга Янисйокского благороднометального проявления следует подчеркнуть следующее. Приуроченность к арсенопиритовой минерализации и чрезвычайно мелкий размер минеральных включений (от 1, редко до 60 мкм). Формы выделения носителей золота и серебра разнообразны: пластинчатые, комковидные, пленочные, удлиненные, жилковидные. Пробность золота средняя и низкая. В зонах с повышенным содержанием арсенопирита установлены две генерации самородного золота и электрума. Установлен ютенбогаардтит - новый для данного рудопроявления минерал, содержащий $\mathrm{Au}$ и $\mathrm{Ag}$.

Работа выполнена в рамках темы НИР № ГР АААА-А18-118020290084-7.

\section{Литература}

1. Минерально-сырьевая база Республики Карелия. Кн. 1. Петрозаводск. Изд-во: Карелия. 2005.278 с.

2. Объяснительная записка к Государственной Геологической карте РФ масштаба 1: 200 000. Издание второе. Карельская серия. Листы Р-35-XXIV, Р-36-XIX. Составители К.И. Степанов, Д.М. Санин, Г.Н. Санина. Редакторы Ю.Б. Богданов, В.Г. Легкова. Эксперты НРС К.Э. Якобсон, Л.Р. Семенова. Москва. МФ ВСЕГЕИ. 2013. 231 с. 